\title{
OPTIMALISASI PENDEKATAN SAINTIFIK DENGAN MODEL DISCOVERY-INQUIRY UNTUK MENINGKATKAN KREATIVITAS DI MADRASAH IBTIDAIYAH
}

\author{
Widya Pratiwi
}

Program Studi Pendidikan Guru Sekolah Dasar, STKIP Majenang

Email: widyapratiwi07@gmail.com

\begin{abstract}
Education on a long term is the most one factor the decides gaps, so the investment in education is a logical way to erase that gap. Recently, the development of the 2013 curriculum entered in the implementation stage. The scientific approaching a way in gaining the goal of the 2013 curriculum Learning is an important thing to boost students understanding and ability in that implementation. But still many found the learning process has not become a means to empower the creative thinking skills of learners because it is still a teacher centered, so the teacher dominates in the classroom. The low of students. Creative thinking showed by their answer base do the book only. It means that the students memorize the answer from the book and they less understand the meaning go fit. Therefore it needs a proper learning model. Later, the discovery inquiry learning model the right one to be implemented in elementary student learning.
\end{abstract}

Keywords: Scientific Approach, discovery-inquiry model, creativity

\begin{abstract}
ABSTRAK
Pendidikan dalam jangka panjang adalah faktor tunggal paling menentukan melebarnya jurang kesenjangan, oleh karena itu investasi dalam bidang pendidikan adalah cara logis untuk menghilangkan kesenjangan tersebut. Saat inipengembangan Kurikulum 2013 sudah memasuki tahap implementasi. Pendekatan Saintifik adalah salah satu cara dalam mencapai tujuan kurikulum 2013. Pembelajaran merupakan hal yang sangat penting untuk mempercepat pemahaman dan keterampilan peserta didik dalam mengimplementasikan kurikulum tersebut. Tetapi masih banyak ditemukan proses pembelajaran belum menjadi sarana untuk memberdayakan keterampilan berpikir kreatif peserta didik karena masih bersifat teacher centered, sehingga guru mendominasi di kelas. Rendahnya berpikir kreatif peserta didik ditunjukkan dengan jawaban yang diberikan terpaku pada jawaban-jawaban yang ada di buku sehingga peserta didik hanya menghafalkan jawaban di buku dan kurang memahami makna jawaban yang disebutkan. Oleh karena itu diperlukan model pembelajaran yang
\end{abstract}


tepat. Sejalan dengan itu, model pembelajaran discovery-inquiry merupakan model yang cocok diterapkan dalam pembelajaran di Madrasah Ibtidaiyah.

Kata Kunci: pendekatan saintifik, model discovery-inquiry, kreativitas

\section{A. PENDAhuluan}

Permasalahan pendidikan di Indonesia pada saat ini sangatlah komplek sehingga mengakibatkan rendahnya mutu pendidikan. Seperti dalam laporan dari hasil TIMSS 2011 membaca siswa SD/MI kelas IV bahwa lebih dari 95\% siswa Indonesia hanya mampu level menengah, sementara lebih dari 50\% siswa Taiwan mampu mencapai level tinggi dan advance. Dengan keyakinan bahwa semua anak dilahirkan sama. Ini artinya dari hasil ini adalah yang diajarkan guru di Indonesia berbeda dengan yang diujikan (distandarkan) internasional. Dengan demikian perbandingan kurikulum SD Kelas IV dan Materi TIMSS kurang sejalan karena beberapa topik yang tidak terdapat pada kurikulum saat ini, sehingga menyulitkan bagi siswa kelas IV yang mengikuti TIMSS.

Sejalan dengan itu UNESCO (EFA Report; 2010) mengenaikualitas pendidikan di Indonesia berada pada posisi 65 dari sebelumnya berada pada posisi 62 dari 128 negara. Ini artinya pendidikan di Indonesia rendah. Kemudian dari laporan Bank Dunia No.16369-IND tahun 1998 (Education in Indonesia from crisis to recovery) menyebutkan bahwa tingkat keterbacaan usia kelas VI Sekolah Dasar di Indonesia hanya mampu meraih skor 51,7 di bawah Filipina $(52,6)$, Thailand $(65,1)$ dan laporan tersebut memperlihatkan bahwa siswa dinilai mengalami kesulitan dalam menjawab soal-soal dalam bentuk uraian yang memerlukan penalaran dan analisis. Hal ini dikarenakan lemahnya kemampuan berpikir kritis dan kreatif para siswa. Keadaan ini mempunyai kecenderungan menurun setiap tahunnya.
Studi yang dilakukan Dyers ${ }^{11}$ menyimpulkan bahwa $2 / 3$ dari kemampuan kreativitas seseorang diperoleh melalui pendidikan, 1/3 sisanya berasal dari genetik. Kebalikannya berlaku untuk kemampuan intelijensia yaitu: 1/3 dari pendidikan, 2/3 sisanya dari genetik. Kemampuan kreativitas diperoleh melalui: Observing (mengamati), Questioning (menanya), Associating (menalar), Experimenting (mencoba), Networking (membentuk jejaring).

Hasil studi ini menekankan kepada kemampuan kreativitas siswa akan terbangun melalui 5 langkah secara sistematis. Temuan yang dikemukakan tersebut sejalan dengan pendekatan Saintifik. Melalui perbaikan dan pembaharuan pendekatan dalam pembelajaran diharapkan dapat mendorong siswa dalam penguasaan terhadap pembentukan sikap, keterampilan dan pengetahuan.para pendidik berupaya sebisa mungkin untuk dapat meningkatkan penguatan proses dengan mengingkatkan kreativitas siswa dengan menerapkan model, strategi pembelajaran dan lain-lain. Kreativitas merupakan fenomena yang kompleks dan beragam. ${ }^{12}$

11 Dyer, J.H et al. 2011. The Innovator's DNA. USA: Harvard Business Review press. Hlm. 17-133.

12 Puccio, G. J(Ed.). 2010. Creativity on Demand: Historical Approaches and Future Trends. New York: Cambridge University Press, Hlm. 153-159 
Studi yang dilakukan Sharp ${ }^{13}$ menyimpulkan bahwa guru dapat membuat peserta didik berani berperilaku kreatif melalui: (1) Tugas yang tidak hanya memiliki satu jawaban tertentu yang benar (banyak/ semua jawaban benar), (2) mentolerir jawaban yang nyeleneh, (3) Menekankan pada proses bukan hanya hasil saja, (4) memberanikan peserta didik untuk mencoba, untuk menentukan sendiri yang kurang jelas/ lengkap informasinya, untuk memiliki interpretasi sendiri terkait dengan pengetahuan atau kejadian yang diamatinya, (5) memberikan keseimbangan antara yang terstruktur dan yang spontan/ ekspresif. Hasil studi ini menyimpulkan bahwa penyempurnaan pola pikir menuju berpusat pada siswa untuk dapat berpikir kreatif. Temuan studi di atas pada dasarnya sejalan dengan upaya pengembangan pembelajaran dalam penguatan proses dalam pendekatan Saintifik.

Studi yang dilakukan Russ ${ }^{14}$ tentang hubungan antara kreativitas dan pembelajaran menyimpulkan bahwa hubungan antara kreativitas dan pembelajaran melibatkan tiga unsur: (1) ciri-ciri kepribadian, seperti rasa percaya diri, mampu untuk mentolerir ambiguitas, rasa ingin tahu dan motivasi, (2) proses emosional, seperti fantasi emosional dalam bermain, kesenangan dalam tantangan, keterlibatan dalam tugas dan toleransi, (3) kemampuan kognitif, seperti berpikir divergen,

13 Sharp, C. 2001. "Developing Young Children's Creativity Through the Arts:What Does Research Have to Offer? ". Invitational Seminar di Chadwick Street Recreation Centre. London, 14 Februari. National Center for Education Statistics, "Indicators of school crime and safety". 2007.

14 Russ, S. W. 2012. "Play and Creativity: Developmental Issues", Scandinavian Journal of Educational Research, Volume 47 No. 3. Hlm 291-303.

kemampuan untuk "mengubah" berpikir (misalnya, dengan mampu menyusun ulang informasi atau mengalihkan pemikiran 'set'), sensitivitas untuk masalah, luasnya pengetahuan dan penilaian.

Untuk mengetahui apakah kebijakan baru mengenai kurikulum telah menyebabkan adanya perubahan, dapat dievaluasi oleh setidaktidaknya tiga indikator. ${ }^{15}$ Pertama, sejauh mana materi-materi baru atau yang direvisi digunakan oleh guru-guru. Kedua, sejauh mana pendekatan-pendekatan pengajaran yang baru telah diterapkan dalam proses kegiatankegiatan belajar di kelas. Ketiga, sejauh mana guru-guru berkeyakinan bahwa kebijakan berdampak kepada perbaikan mutu dan proses pembelajaran. Ketiga indikator tersebut secara bersama-sama akan menentukan berhasil tidaknya tujuan-tujuan perubahan pendidikan.

Rendahnya mutu dapat dilihat dari berbagai bidang, di antaranya kemampuan guru, kemampuan siswa, manajemen sekolah, akses terhadap pendidikan dan output pendidikan. Banyak dari kalangan status ekonomi rendah, masyarakat terpencil memperoleh pendidikan sangat sulit. Hal tersebut mengambarkan kemampuan siswa dengan sistem pendidikan sampai sekarang belum mencapai level optimal.

Salah satu upaya peningkatan mutu pendidikan dilakukan melalui perubahan kurikulum 2013 yang menerapkan pendekatan Saintifik dalam proses pembelajarannya. Pendekatan ini bertujuan meningkatkan kemampuan berpikir kritis dan logis dalam memecahkan masalah. Berdasarkan pengamatan peneliti dan hasil penelitian berpikir kritis dan
15 Fullan, I, M.G. 2001. The New Meaning of Educational Change. London: RoutledgeFalmer.


kreatif Fachrurozi ${ }^{16}$ menunjukkan kemampuan berpikir kritis khususnya untuk Sekolah Dasar (SD/) masih rendah.

Mengetahui pentingnya implementasi pendekatan Saintifik dengan model DiscoveryInquiry di Madrasah Ibtidaiyah, dipilihah model discovery-inquiry sebagai solusi agar siswa terdorong untuk terlibat langsung dalam proses pembelajaran yang dimulai dari kegiatan orientasi, merumuskan masalah, mengajukan hipotesis, merancang pendekatan investigasi dalam bentuk eksperimen, mengumpulakan data, menguji hipotesis serta merumuskan kesimpulan dan terakhir memiliki sikap ilmiah. Berdasarkan penjelasan di atas yang perlu dipertanyakan yaitu: bagaimana langkahlangkah pendekatan Saintifik dengan model discovery-inquiry dalam kurikulum 2013 ?

\section{B. PEMBAHASAN}

Pembahasan kali ini akan membahas tentang optimalisasi pendekatan Saintifik dengan model discovery-inquiry di Madrasah Ibtidaiyah. Ada dua pokok penting yang dibahas, yaitu konsep pendekatan Saintifik dan model discovery-inquiry.

Pendidikan berintikan interaksi antara pendidik dengan peserta didik dalam upaya membantu peserta didik menguasai tujuantujuan pendidikan. ${ }^{17}$ Tujuan pendidikan Nasional sesuai pasal 3 UU No. 20 SISDIKNAS Tahun 2003 bahwa berkembangnya potensi peserta didik agar menjadi manusia yang beriman

16 Fauziyah, N. 2011. "Analisis Kemampuan Guru dalam Mengembangkan Keterampilan Berpikir Kreatif Siswa Dasar Kelas V pada Pembelajaran Ilmu Pengetahuan Alam". UPI. Jurnal Pedagogik Pendidikan Dasar, Volume 3 No. 1.

17 Nana S Sukmadinata. 2014. Pengembangan Kurikulum Teori dan Praktek. Bandung: PT Remaja Rosdakarya. dan bertakwa kepada Tuhan Yang Maha Esa, berakhlak mulia, sehat, berilmu, cakap, kreatif, mandiri, dan menjadi warga negara yang demokratis serta bertanggung jawab.

Pendidikan, dalam jangka panjang, adalah faktor tunggal paling menentukan melebarnya jurang kesenjangan, oleh karena itu investasi dalam bidang pendidikan adalah cara logis untuk menghilangkan kesenjangan tersebut. Mulyasa $^{18}$ mengatakan bahwa aktivitas dan kreativitas peserta didik dalam proses pembelajaran dapat dikembangkan dengan memberikan kepercayaan, komunikasi yang bebas, pengarahan diri, dan pengawasan yang tidak terlalu ketat. Penerapan dalam pembelajaran dapat dilakukan dengan cara: (a) mengembangkan keberanian dan rasa percaya diri peserta didik, serta mengurangi perasaanperasaan yang kurang menyenangan; (b) memberi kesempatan kepada seluruh peserta didik untuk berkomunikasi secara aktif dan terarah; (c) melibatkan peserta didik dalam menentukan tujuan belajar dan penilaian hasilnya; (d) memberikan pengawasan yang tidak terlalu ketat dan tidak otoriter; (e) melibatkan mereka secara aktif, kreatif, dan menyenangkan dalam proses pembelajaran secara keseluruhan.

Berkaitan dengan peningkatan aktivitas dan kreativitas peserta didik dalam upaya peningkatan kualitas pembelajaran, Widada mengemukakan berbagai pendekatan sebagai berikut. (a) Pendekatan akan harga diri (selfesteem approach) guru tidak hanya mengarahkan peserta didik untuk mempelajari materi ilmiah saja, tetapi pengembangan sikap harus mendapat perhatian secara proposional. (b) Creative

18 Mulyasa, E. 2010. Kurikulum Tingkat Satuan Pendidikan Sebuah Panduan Praktis, Bandung: Bumi Aksara. 
Approach pendekatan ini dikembangkannya problem solving, brain storming, inquiry, dan role playing. (c) Value Clarification and moral development approach. Dalam pendekatan ini pengembangan pribadi menjadi sasaran utama, pendekatan holistik dan humanistik menjadi ciri utama dalam pengembangan potensi manusia menuju self-actualization. Dalam situasi yang demikian pengembangan intektual akan mengiringi pengembangan pribadi peserta didik. (d) Multi Talent Approach.

Berdasarkan berbagai teori tersebut, dapat dikatakan bahwa pendidikan yang mampu mendukung pembangunan di masa yang akan datang adalah pendidikan yang mampu mengembangkan potensi peserta didik, sehingga yang bersangkutan berani menghadapi, mampu memecahkan, dan berhasil mengatasi masalah kehidupan yang dihadapinya. Oleh karena itu, pendidikan harus menyentuh potensi kompetensi peserta didik.

Berdasarkan hal itu, rendahnya kreativitas dalam menentukan hasil belajar menjadi fokus perhatian yang cukup menarik untuk diteliti. Menanggapi fenomena ini, agar proses pembelajaran dapat memicu hasil belajar yang meningkat berorientasi model discovery-inquiry kepada 5 tahapan langkah-langkah: Observing (mengamati), Questioning (menanya), Associating (menalar), Experimenting (mencoba), Networking (Membentuk jejaring) perlu mengunakan pendekatan yang tepat.

Pendekatan Saintifik sangat relevan dengan teori belajar Bruner, Piaget, dan Vygotsky. Teori belajar Bruner disebut juga teori belajar penemuan. Ada empat hal pokok yang berkaitan dengan teori belajar Bruner. Pertama, individu hanya belajar dan mengembangkan pikirannya apabila ia menggunakan pikirannya. Kedua, dengan melakukan proses kognitif dalam proses penemuan, peserta didik akan memperoleh sensasi dan kepuasan intelektual yang merupakan suatu penghargaan intrinsik. Ketiga, satu-satunya cara agar seseorang dapat mempelajari teknik-teknik dalam melakukan penemuan adalah ia memiliki kesempatan untuk melakukan penemuan. Keempat, dengan melakukan penemuan, retensi ingatan peserta didik akan menguat. Empat hal di atas bersesuaian dengan proses kognitif yang diperlukan dalam pembelajaran dengan pendekatan Saintifik.

Hal tersebut sejalan dengan lampiran Permendikbud no. 65 tahun 2013 tentang Standar Proses Kurikulum 2013. Proses Pembelajaran pada satuan pendidikan diselenggarakan secara interaktif, inspiratif, menyenangkan, menantang, memotivasi siswa untuk berpartisipasi aktif, serta memberikan ruang yang cukup bagi prakarsa, kreativitas, dan kemandirian sesuai dengan bakat, minat, dan perkembangan fisik serta psikologis siswa. Proses pembelajaran yang dikembangkan dalam Kurikulum 2013 menuntut untuk berpendekatan Saintifik dan kontekstual. Hal ini diharapkan guna menghasilkan High Order Thinking (HOT) sejak dini. Pendekatan Saintifik ini meliputi mengamati, menanya, menalar, mencoba, dan mengkomunikasikan.

Menjawab permasalahan tersebut, ditawarkan sebuah pendekatan pembelajaran yaitu pendekatan Saintifik dengan model discovery-inquiry. Metode ini memudahkan guru atau pengembang kurikulum untuk memperbaiki proses pembelajaran, yaitu dengan memecah proses ke dalam langkah-langkah atau tahapan-tahapan secara terperinci yang memuat instruksi untuk siswa melaksanakan kegiatan pembelajaran. Untuk keberhasilan pendekatan ilmiah (Saintifik Approach) 
diperlukan waktu khusus untuk menyampaikan intruksi pembelajaran. Alokasi waktu yang sedikit akan membatasi aspek interaktif dan kooperatif, sedangkan pekerjaan rumah harus dirancang dengan cermat sehingga dapat memotivasi peserta didik. Peserta didik merasa terlibat dalam proses belajar melalui pendekatan Saintifik karena mereka terus bekerja. Pada pelaksanaan awal guru harus mempersiapkan skenario pembelajaran yang matang. ${ }^{19}$

\section{Pendekatan Saintifik}

Pembelajaran dengan pendekatan Saintifikadalah pembelajaran yang terdiriatas kegiatan mengamati (untuk mengidentifikasi masalah yang ingin diketahui), merumuskan pertanyaan (dan merumuskan hipotesis), mengumpulkan data/ informasi dengan berbagai teknik, mengolah/ menganalisis data/ informasi dan menarik kesimpulan dan mengkomunikasikan hasil yang terdiri dari kesimpulan dan mungkin juga temuan lain yang di luar rumusan masalah untuk memperoleh pengetahuan, keterampilan dan sikap. Langkah-langkah tersebut dapat dilanjutkan dengan kegiatan mencipta.

Pendekatan saintifik sangat relevan dengan teori belajar Bruner, Piaget, dan Vygotsky berikut ini. Teori belajar Bruner disebut juga teori belajar penemuan. Ada empat hal pokok yang berkaitan dengan teori belajar Bruner (dalam Carin \& Sund, 1975). Pertama, individu hanya belajar dan mengembangkan pikirannya apabila ia menggunakan pikirannya. Kedua, dengan melakukan proses kognitif dalam proses penemuan, peserta didik akan memperoleh

19 KarimJ.Nasr,C.DuaneThomas.2004. "Studentcentered, Concept-embedded Problem-based Engineering Thermodynamics". International Journal Engineering Education, Volume 20 No. 4. Hlm. 660 - 670 . sensasi dan kepuasan intelektual yang merupakan suatu penghargaan intrinsik. Ketiga, satu-satunya cara agar seseorang dapat mempelajari teknik-teknik dalam melakukan penemuan adalah ia memiliki kesempatan untuk melakukan penemuan. Keempat, dengan melakukan penemuan, retensi ingatan peserta didik akan menguat. Empat hal di atas bersesuaian dengan proses kognitif yang diperlukan dalam pembelajaran dengan pendekatan saintifik.

\section{Tujuan Pembelajaran dengan Pendekatan Saintifik}

Tujuan pembelajaran dengan pendekatan saintifik adalah sebagai berikut.

a. Meningkatkan kemampuan intelektual, khususnya kemampuan berpikir tingkat tinggi peserta didik,

b. Membentuk kemampuan peserta didik dalam menyelesaikan suatu masalah secara sistematik,

c. Memperoleh hasil belajar yang tinggi,

d. Melatih peserta didik dalam mengkomunikasikan ide-ide, khususnya dalam menulis karya ilmiah, serta

e. Mengembangkan karakter peserta didik.

\section{Prinsip Pembelajaran dengan Pendekatan Saintifik}

Prinsip-prinsip pembelajaran dengan pendekatan saintifik adalah sebagai berikut.

a. Berpusat pada peserta didik yaitu kegiatan aktif peserta didik secara fisik dan mental dalam membangun makna atau pemahaman suatu konsep, hukum/ prinsip,

b. Membentuk students' self concept yaitu membangun konsep berdasarkan pemahamannya sendiri,

c. Menghindari verbalisme, 
d. Memberikan kesempatan pada peserta didik untuk mengasimilasi dan mengakomodasi konsep, hukum, dan prinsip,

e. Mendorong terjadinya peningkatan kecakapan berpikir peserta didik,

f. Meningkatkan motivasi belajar peserta didik,

g. Memberikan kesempatan kepada peserta didik untuk melatih kemampuan dalam komunikasi,

h. Memungkinkan adanya proses validasi terhadap konsep, hukum, dan prinsip yang dikonstruksi peserta didik dalam struktur kognitifnya,

i. Melibatkan keterampilan proses sains dalam mengonstruksi konsep, hukum, atau prinsip,

j. Melibatkan proses kognitif yang potensial dalam merangsang perkembangan intelektual, khususnya keterampilan berpikir tingkat tinggi peserta didik.

4. Langkah Pembelajaran dengan Pendekatan Saintifik dengan model discoveryinquiry

Secara umum pembelajaran dengan pendekatan saintifik dilakukan melalui sejumlah langkah sebagai berikut.

a. Melakukan pengamatan terhadap aspek-aspek dari suatu fenomena untuk mengidentifikasi masalah,

b. Merumuskan pertanyaan berkaitan dengan masalah yang ingin diketahui dan menalar untuk merumuskan hipotesis atau jawaban sementara berdasarkan pengetahuan dan pengalaman yang dimiliki,

c. Mencoba/ mengumpulkan data atau informasi dengan berbagai teknik,

d. Mengasosiasi/ menganalisis data atau informasi untuk menarik kesimpulan,

e. Mengkomunikasikan kesimpulan,

f. Mencipta.

5. Model pembelajaran discovery-inquiry dalam pembelajaran

Aktifitas belajar dengan Pendekatan Saintifik ${ }^{20}$

\begin{tabular}{|l|l|}
\hline \multicolumn{1}{|c|}{ KEGIATAN } & \multicolumn{1}{c|}{ AKTIVITAS BELAJAR } \\
\hline Mengamati (Observing) & $\bullet \begin{array}{l}\text { Melihat, mengamati, membaca, mendengar, menyimak (tanpa dan } \\
\text { dengan alat) }\end{array}$ \\
\hline Menanya (Questioning) & $\bullet \begin{array}{l}\text { Mengajukan pertanyaan dari yang faktual sampai ke yang bersifat } \\
\text { hipotesis }\end{array}$ \\
\hline $\begin{array}{l}\text { Pengumpulan data } \\
\text { (Experimenting) }\end{array}$ & $\begin{array}{l}\text { Diawali dengan bimbingan guru sampai dengan mandiri (menjadi } \\
\text { suatu kebiasaan) }\end{array}$ \\
\hline
\end{tabular}

20 Kemdikbud. 2013b. Pendekatan Saintifik (Ilmiah) dalam Pembelajaran. Jakarta: Pusbangprodik. 


\begin{tabular}{|l|l|}
\hline Mengasosiasi (Association) & $\begin{array}{l}\text { Menganalisis data dalam bentuk membuat kategori,menentukan } \\
\text { hubungan data/ kategori }\end{array}$ \\
& $\begin{array}{l}\text { Menyimpulkan dari analisis data } \\
\text { Dimulai dari unstructured-unistructure-multi structure-complicated } \\
\text { structure }\end{array}$ \\
\hline $\begin{array}{l}\text { Mengkomunikasikan } \\
\text { (Communicating) }\end{array}$ & $\begin{array}{l}\text { - Menyampaikan hasil konseptualisasi } \\
\text { Dalam bentuk lisan, tulisan, diagram, bagan, gambar atau media } \\
\text { lainnya }\end{array}$ \\
\hline
\end{tabular}

6. Optimalisasi peran guru dalam implementasi pendekatan Saintifik dengan model discovery-inquiry

Komponen terpenting implementasi kurikulum adalah pelaksanaan proses pembelajaran yang diselenggarakan di dalam dan/ atau luar kelas untuk membantu peserta didik mencapai kompetensi sikap, pengetahuan dan keterampilan. Peraturan Menteri Pendidikan dan Kebudayaan nomor 65 tahun 2013 tentang Standar Proses menyatakan bahwa proses pembelajaran menggunakan pendekatan atau metode pembelajaran yang sesuai dengan karakteristik peserta didik dan mata pelajaran. Di antara pendekatan dan metode yang dianjurkan dalam Standar Proses tersebut adalah pendekatan saintifik dengan model discovery-inquiry

Walaupun banyak guru SD/Madrasah Ibtidaiyah di Indonesia telah mengenal metodetersebut,pengimplementasianmetode tersebut di kelas merupakan hal yang belum biasa. Untuk mengimplementasikannya, guru memerlukan langkah-langkah yang memberikan gambaran utuh kegiatankegiatan pembelajaran operasional apa saja yang dilaksanakan pada tahap pendahuluan, inti, dan penutup. Sehubungan dengan hal tersebut, perlu dijabarkan proses pembelajaran yang secara rinci memberikan petunjuk pembelajaran bagaimana metode tersebut diimplementasikan pada kegiatan belajar mengajar pada tahap pendahuluan, inti, dan penutup.

Kegiatan pembelajaran meliputi kegiatan pendahuluan, inti, dan penutup. Kegiatan pendahuluan bertujuan untuk menciptakan suasana awal pembelajaran yang efektif yang memungkinkan peserta didik dapat mengikuti proses pembelajaran dengan baik. Sebagai contoh, ketika memulai pembelajaran, guru menyapa anak dengan nada bersemangat dan gembira, mengecek kehadiran para peserta didik, menyampaikan tujuan pembelajaran dan kegiatan pembelajaran yang akan dilakukan.

Kegiatan inti merupakan kegiatan utama dalam proses pembelajaran karena terkait langsung dengan pencapaian tujuan pembelajaran. Kegiatan inti dalam pendekatan saintifik ditujukan untuk memperoleh konsep, hukum, atau prinsip oleh peserta didik dengan bantuan guru melalui langkah-langkah kegiatan yang diberikan di muka. Pada akhir kegiatan inti validasi terhadap konsep, hukum, atau prinsip yang telah dikonstruk oleh peserta didik dilakukan

Kegiatan penutup ditujukan untuk beberapa hal pokok. Pertama, pengayaan materi pelajaran yang dikuasai peserta didik. Pengayaan dapat dilakukan dengan memberikan tugas kepada peserta didik 
membaca buku-buku pelajaran atau sumber informasi lainnya untuk memantapkan pemahaman materi yang telah dibelajarkan atau memahami materi lain yang berkaitan. Guru juga dapat meminta peserta didik mengakses sumber-sumber dari internet, baik berupa animasi maupun video yang berkaitan dengan materi yang telah dibelajarkan. Dalam hal ini, sebaiknya guru memberikan situs-situs internet yang berkaitan dengan materi pelajaran yang telah dibelajarkan. Pengayaan dapat juga dilakukan dengan meminta peserta didik melakukan percobaan di rumah, yang berkaitan dengan materi yang telah dibelajarkan, yang dapat dilakukan dengan aman. Kedua, guru dapat memberikan kegiatan remedi apabila ada peserta didik yang belum mencapai kompetensi yang diharapkan. Selain itu, guru dapat memberi PR dan memberitahuhan materi/ kompetensi berikutnya yang akan dipelajari.

Peran guru dalam pembelajaran sangat vital. Guru dituntut untuk dapat menciptakan kegiatan pembelajaran yang memungkinkan siswa menguasai tujuan pembelajaran secara optimal. ${ }^{21}$ Untuk mengaktifkan siswa dalam kegiatan pembelajaran. Guru hendaknya mampu memusatkan perhatian siswa pada tujuan pembelajaran dan memberikan kesempatan siswa untuk berpartisipasi dalam pembelajaran dengan membangkitkan motivasi siswa. Banyak yang dilakukan guru dalam memainkan perannya sebagai fasilitator. Di antaranya sebagai berikut.

1. Menunjukan sikap positif terhadap siswa.

2. Memberikan kegiatan yang bermakna, sesuai dan menarik bagi siswa.

21 Suciati. (2007). Belajar dan Pembelajaran 2.Jakarta: Universitas Terbuka.
3. Menunjukan semangat mengajar.

4. Menerapkan disiplin secara fleksibel sehingga tercipta suasana pembelajaran yang efektif.

5. Memberikan kesempatan kepada siswa untuk terlibat aktif dalam berbagai kegiatan yang menuntut komunikasi antar-siswa dan melakukan kerjasama.

6. Memberikan kesempatan kepada siswa untuk menilai diri sendiri.

7. Memberikan balikan positif terhadap hasil kerja siswa.

8. Memberikan kesempatan kepada siswa untuk memperoleh kebanggaan dari hasil kerjanya.

\section{PENUTUP}

Implementasi pendekatan Saintifik dengan model discovery-inquiry di sekolah dasar dapat meningkatkan kemampuan berpikir kritis siswa. Dengan model discovery-inquiry pembelajaran diarahkan untuk mendorong peserta didik mencari tahu dari berbagai sumber observasi, bukan diberi tahu. Sejalan dengan itu juga pembelajaran diarahkan untuk mampu merumuskan masalah (menanya), bukan hanya menyelesaikan masalah (menjawab); pembelajaran diarahkan untuk melatih berpikir analitis (pengambilan keputusan) bukan berpikir mekanistis (rutin); pembelajaran menekankan pentingnya kerjasama dan kolaborasi dalam menyelesaikan masalah.

Pengunaan model discovery-inquiry memberikan dampak positif bagi kreativitas siswa. Walaupun dirasa masih perlu banyak adaptasi dalam hal penggunaan lingkungan belajar dan media-media yang relevan. Terkadang persiapan dan perencanaan yang terbatas, waktu yang terbatas membuat kegiatan pembelajaran terutama untuk meningkatkan 
kemampuan berpikir kreatif masih jauh dari optimal, akan tetapi apabila ini digunakan secara konsisten dan sesuai dengan kontrol belajar yang tepat akan memungkinkan kemampuan berpikir kreatif siswa akan meningkat signifikan. Karena mereka dituntut untuk open minded dengan situasi pembelajaran yang menuntut untuk berpikir, mencari tahu, bertanya, bereksplorasi, mencari pemecahan masalah dan memberikan kesimpulan. Oleh karena itu model ini cocok diterapkan dalam pembelajaran di Madrasah Ibtidaiyah.

\section{DAFTAR PUSTAKA}

Dyer, J.H et al. (2011), The Innovator's DNA, USA: Harvard Business Review press. Hal. 17-133.

Fauziyah, N. (2011), "Analisis kemampuan guru dalam mengembangkan ketrampilan berfikir kreatif siswa dasar kelas V pada pembelajaran ilmu pengetahuan alam". UPI. Jurnal Pedagogik Pendidikan Dasar, Volume 3 No. 1.

Fullan, I, M.G. (2001), The New Meaning of Educational Change, London: RoutledgeFalmer.

Karim J. Nasr, C. Duane Thomas. (2004), "Student-centered, Conceptembedded Problem-based Engineering Thermodynamics". International Journal Engineering Education, Volume 20 No. 4.

Kemdikbud. (2013b), Pendekatan Saintifik (Ilmiah) dalam Pembelajaran. Jakarta: Pusbangprodik.

Mulyasa, E. (2010), Kurikulum Tingkat Satuan Pendidikan Sebuah Panduan Praktis, Bandung: Bumi Aksara.
Nana S Sukmadinata. (2014), Pengembangan Kurikulum Teori dan praktek. Bandung: PT Remaja Rosdakarya.

Puccio, G. J (Ed.). (2010), Creativity on Demand: Historical Approaches and Future Trends, New York: Cambridge University Press.

Russ, S. W. (2012), "Play and Creativity: Developmental Issues", Scandinavian Journal of Educational Research, Volume 47 No. 3.

Sharp, C. (2001), "Developing Young Children's Creativity through the Arts: What Does Research Have to Offer?" Invitational Seminar di Chadwick Street Recreation Centre. London, 14 Februari.

Suciati. (2007), Belajar dan Pembelajaran 2, Jakarta: Universitas Terbuka. 